\title{
RESGATANDO TEXTOS CLÁSSICOS
}

\author{
Olga Lucia Castreghini de Freitas FIRKOWSKI ${ }^{*}$
}

Temos o prazer de incorporar à seção "Resgate de Textos Clássicos", desta edição da Revista RA' E GA, o texto Regionalização e Rede Urbana, de autoria de Michel Rochefort, cuja publicação apresenta ao leitor uma série de oportunidades:

- possibilita a recuperação do documento referente a uma das inúmeras palestras proferidas por tão renomado geógrafo, que teve papel relevante na consolidação da Geografia no século XX. A palestra que deu origem ao texto foi proferida em agosto de 1982, na cidade de Presidente Prudente (SP) e publicada no mesmo ano no número 4 do Caderno Prudentino de Geografia, à época uma simples e "caseira" publicação organizada pela seção local da AGB, que tive o privilégio de ver nascer;

- permite revisitar uma importante discussão que se reveste de atualidade, na medida em que o tema central do texto sempre esteve entre as mais relevantes discussões da Geografia Urbana.
Numa interessante comparação entre o Brasil e a Costa do Marfim, o texto analisa a constituição da rede urbana e do processo de planejamento, sobretudo no que diz respeito à regionalização, priorizando a realidade dos países do Terceiro Mundo.

Privilegia, assim, a reflexão acerca das relações entre Geografia e Planejamento, transitando por conceitos como: regionalização, concentração da indústria e desequilíbrios regionais, salientando, também, a importante participação do setor terciário na estruturação do espaço geográfico.

Michel Rochefort, professor do Instituto de Geografia da Universidade de Paris I - Pantheon - Sorbonne, teve uma sólida contribuição à constituição da Geografia, em especial à Geografia Urbana, tanto mundialmente quanto em relação ao Brasil. Como aprofundamento dos conteúdos tratados no artigo ora publicado, recomenda-se a leitura do livro Redes e Sistemas. Ensinando sobre o Urbano e a Região (ROCHEFORT, M. Redes e Sistemas. Ensinando sobre o Urbano e a Região. São Paulo: Hucitec, 1998, 174 p.)

\footnotetext{
* Professora Adjunta do Departamento de Geografia - UFPR.
} 